- FINANSE I PRAWO FINANSOWE.

- Journal of Finance and Financial Law

Wrzesień/September 2020 • vol. 3(27): 175-191

http://dx.doi.org/10.18778/2391-6478.3.27.10

\title{
UISZCZANIE OPŁAT SĄDOWYCH ZA POŚREDNICTWEM DOSTAWCÓW USŁUG PŁATNICZYCH
}

\author{
Bartosz Wyżykowski* \\ Radca prawny \\ Wydział Prawa, Administracji i Ekonomii, Uniwersytet Wrocławski
}

\section{Streszczenie}

Celem artykułu jest wykazanie, że dla dochowania terminu uiszczenia opłat sądowych w postępowaniu cywilnym i sądowo-administracyjnym przesądzające znaczenie ma data złożenia zlecenia płatniczego, nie zaś dzień otrzymania środków przez sąd (dzień uznania rachunku sądu), bez względu na to, za pośrednictwem jakiego operatora transakcja jest inicjowana, pod warunkiem, że ma on status dostawcy usług płatniczych. Przedmiotem analizy jest w szczególności przegląd aktualnego orzecznictwa SN i NSA.

Słowa kluczowe: opłata sądowa, postępowanie cywilne, postępowanie sądowo-administracyjne, dostawca usług płatniczych, usługa płatnicza.

JEL Class: K15, K40, K41.

* Artykuł prezentuje poglądy Autora i nie powinien być traktowany jako stanowisko innych podmiotów, organów lub instytucji. 


\section{WSTĘP}

Nieuiszczenie opłaty sądowej bądź też uiszczenie jej w sposób nieterminowy, może pociągać za sobą daleko idące skutki procesowe w postaci zwrotu pisma (pozwu) lub wniosku, czy też odrzucenia środka zaskarżenia (w szczególności chodzi o sytuacje, gdy opłata uiszczana jest na wezwanie sądu i strona związana jest w tym zakresie określonym - najczęściej tygodniowym - terminem) ${ }^{1}$. Stąd kluczowym jest, aby uiszczający opłatę miał pewność, że w przypadku wybranej przez niego metody płatności i wybranego dostawcy usług płatniczych ${ }^{2}$ (dalej: dostawca/dostawcy), datą jej uiszczenia uznanawany był dzień zainicjowania transakcji (dzień złożenia zlecenia płatniczego/otrzymania zlecenia przez dostawcę), nie zaś dzień otrzymania środków przez sąd (dzień uznania rachunku sądu). W przeciwnym wypadku nigdy nie miałby pewności, że opłata uiszczona została terminowo. Szczególne wątpliwości pojawiają się, gdy transakcja inicjowana jest za pośrednictwem dostawcy niemającego statusu banku ${ }^{3}$ lub instytucji kredytowej ${ }^{4}$ (oddziału instytucji kredytowej ${ }^{5}$ ). Na gruncie - zwłaszcza dawniejszego - orzecznictwa SN nie było oczywiste, że w takim wypadku jako datę uiszczenia opłaty należy traktować dzień złożenia zlecenia płatniczego. Tymczasem, na podstawie obowiązujących przepisów należy przyjąć, że datą uiszczenia opłaty sądowej zawsze będzie dzień złożenia zlecenia płatniczego, jeżeli transakcja inicjowana jest za pośrednictwem dostawcy. W tym celu dokonywany jest przegląd aktualnego orzecznictwa SN i NSA, a także analiza obowiązujących przepisów, uwzględniając, że obecnie świadczenie usług płatniczych $\mathrm{W}$ przewarzającej mierze regulowane jest na mocy norm stanowiących implementację prawa unijnego.

\section{1. ŚWIADCZENIE USŁUG PŁATNICZYCH}

Wątpliwości w zakresie tego, jakimi metodami (w jaki sposób) można (należy) uiszczać opłaty sądowe bezgotówkowo i z jaką datą opłatę taką należy uznać za uiszczoną (w szczególności, gdy następuje to wskutek wykonania wezwania sądu), wynikają z tego, iż kwestia ta nie została precyzyjnie uregulowana ani na gruncie postępowania cywilnego, ani na gruncie postępowania sądowo-

${ }^{1}$ Zob. np. art. $130 \S 1,2,6$ i 7 , art. $130^{2} \S 1$ i 2 , art. $328 \S 4$, art. $344 \S 3$, art. $373 \S 1$, art. $398^{6}$ $\S 2$ i 3 , art. $424^{6} \S 3$, art. $424^{8} \S 1$, art. $480^{3} \S 3$, art. $511^{1} \S 1$ i 2 oraz art. $767^{3} \S 1$ k.p.c. [Ustawa z dnia 17 listopada 1964 r...] oraz art. 220 § 1 p.p.s.a. [Ustawa z dnia 30 sierpnia 2002 r...].

${ }^{2}$ Katalog dostawców zawarty jest w art. 4 ust. 2 UUP [Ustawa z dnia 19 sierpnia $\left.2011 \mathrm{r} . ..\right]$.

${ }^{3}$ Art. 2 p.b. [Ustawa z dnia 29 sierpnia 1997 r...].

${ }^{4}$ Art. 4 ust. 1 pkt 17 p.b.

${ }^{5}$ Art. 4 ust. 1 pkt 18 p.b. 
- administracyjnego. Obowiązujące przepisy ${ }^{6}$ nie regulują w sposób szczegółowy jaką metodą może (ma) być inicjowana ${ }^{7} \mathrm{i}$ wykonana ${ }^{8}$ transakcja płatnicza, ani też nie określają kręgu podmiotów, z usług których można (należy) w tym zakresie korzystać9. Nie tylko nie wyjaśniają, z jaką datą daną opłatę należy uznać za uiszczoną, ale nie definiują, co należy rozumieć pod pojęciem uiszczenia opłaty sądowej. Podobny problem pojawił się zresztą na gruncie stosunków cywilnoprawnych, wszak materialne przepisy prawa cywilnego nie przesądzają, czy spełnienie świadczenia bezgotówkowego następuje w dniu zlecenia transakcji czy też w dniu uznania rachunku płatniczego wierzyciela. W orzecznictwie SN opowiedziano się za drugim stanowiskiem, przyjmując, że spełnienie świadczenia bezgotówkowego następuje w dniu uznania rachunku wierzyciela ${ }^{10}$. Nie wydaje się jednak zasadne, aby takie rozwiązanie mocą analogii stosować do uiszczania opłat sądowych, a więc należności o charakterze publicznoprawnym. Główną sankcją dla dłużnika z tytułu opóznienia lub zwłoki w świadczeniu cywilno-prawnym (wykonywanym bezgotówkowo) jest obowiązek zapłaty (na żądanie wierzyciela) odsetek za opóznienie (choć oczywiście w konkretnych okolicznościach możliwe będą dalej idące skutki, np. wypowiedzenie umowy, odszkodowanie). Tymczasem nieuiszczenie lub nienależyte uiszczenie opłaty sądowej może skutkować nieodwracalną wadliwością czynności procesowej (np. odrzucenie środka zaskarżenia).

Mimo dynamicznego rozwoju technologicznego i pojawiania się coraz nowszych metod bezgotówkowych płatności (płatności elektroniczne, zdalne, mobilne, np. BLIK ${ }^{11}$ lub płatności pay-by-link ${ }^{12}$,), omawiane zagadnienie budzi wątpliwości w praktyce. Po pierwsze, transakcje płatnicze $\mathrm{z}$ istoty stanowią dosyć specyficzny i skomplikowany rodzaj usług. W proces inicjowania i wykonywania

${ }^{6}$ Ustawa z dnia 28 lipca 2005 r..., Rozporządzenie Ministra Sprawiedliwości z dnia 21 marca 2016 r... oraz Rozporządzenie Rady Ministrów z dnia 16 grudnia 2003 r...

${ }^{7}$ M. Masłowski wskazuje, że doniosłość aktu zainicjowania określonej transakcji i jego wyróżnienie wprost $\mathrm{w}$ definicji transakcji płatniczej wydaje się wskazywać, że wyrażenie to w kontekście przepisów UUP należy rozumieć szerzej, tj. również jako czynności obejmujące uwierzytelnienie oraz autoryzację [Masłowski 2019].

${ }^{8}$ Przez wykonanie transakcji należy rozumieć przyjęcie wpłaty, a także dokonanie transferu lub wypłaty przez dostawcę [art. 2 pkt 29 UUP].

${ }^{9} \mathrm{~W}$ postanowieniu z 18 grudnia 2018 r..., SN słusznie zauważył, że ani u.k.s.c. ani rozporządzenie MS nie określa, w jakich placówkach (poza kasą sądu) można dokonywać wpłat opłat sądowych.

${ }^{10}$ Zob. np. postanowienie SN z 18 grudnia 2018...; uchwała SN z 4 stycznia 1995 r... oraz wyrok SN z 12 lipca 1996 r...: 190].

${ }^{11}$ Przez BLIK należy rozumieć zarówno aplikację, niekartowy schemat płatniczy, jak również system płatności stworzony przez Polski Standard Płatności sp. z o.o.

${ }^{12}$ Pod pojęciem pay-by-link rozumie się przelew bezpośredni uruchamiany specjalnie wygenerowanym linkiem. Wszystkie dane potrzebne do wykonania przelewu są wypełniane automatycznie, a klient musi tylko zatwierdzić przelew w systemie bankowości internetowej [Balkowski 2018: 7]. 
transakcji bardzo często zaangażowane są liczne inne podmioty, których błędy lub zaniechania mogą skutkować nienależytym wykonaniem transakcji. Po drugie, obecnie coraz częciej transakcje bezgotówkowe inicjowane są za pośrednictwem niebankowch dostawców. Świadczenie usług płatniczych w krajach UE regulowane jest na podstawie legislacji krajowych stanowiących implementację PSD2 [Dyrektywa Parlamentu Europejskiego i Rady (UE) 2015/2366 z dnia 25 listopada $2015 \mathrm{r}$. w sprawie usług płatniczych w ramach rynku wewnętrznego, zmieniająca dyrektywy 2002/65/WE, 2009/110/WE, 2013/36/UE i rozporządzenie (UE) $\mathrm{nr}$ 1093/2010 oraz uchylająca dyrektywę 2007/64/WE (OJ L 337, 23.12.2015, s. 35-127]. W Polsce aktem, który wdrożył tę dyrektywę jest UUP. Przepisy tej ustawy stosuje się do usług płatniczych świadczonych na terytorium RP lub w obrocie $\mathrm{z}$ innymi państwami członkowskimi, z zastrzeżeniem wyjątków wynikających $z$ art. 5 ust. 2-4 oraz art. 6-6e UUP (analiza tych wyjątków wykracza poza ramy niniejszego opracowania). Działalność w zakresie świadczenia usług płatniczych może być wykonywana przez każdy podmiot posiadajcy status dostawcy. UUP zawiera zamknięty katalog takich dostawców ${ }^{13}$, który oprócz banków (instytucji kredytowych) obejmuje m.in. instytucje płatnicze, instytucje pieniądza elektronicznego, małe instytucje płatnicze, biura usług płatniczych. Wszystkie te podmioty mają prawo świadczyć - w zakresie objętym zezwoleniem lub wpisem - usługi płatnicze. Dostawcami są także spółdzielcze kasy oszczednościowo-kredytowe oraz Poczta Polska S.A. w zakresie, w jakim odrębne przepisy uprawniają te podmioty do świadczenia usług płatniczych. Do usług płatniczych zalicza się w szczególności przekaz pieniężny oraz polecenie przelewu. Usługa przekazu pieniężnego świadczona jest bez pośrednictwa rachunku płatniczego prowadzonego dla płatnika i w uproszczeniu polega na transferze środków pieniężnych otrzymanych od płatnika do odbiorcy ${ }^{14}$. Natomiast usługa polecenia przelewu prowadzi do uznania rachunku płatniczego odbiorcy, na podstawie dyspozycji płatnika dla którego dostawca również prowadzi rachunek płatniczy ${ }^{15}$.

\section{UISZCZENIE OPŁATY SĄDOWEJ PRZEKAZEM PIENIĘŻNYM, POLECENIEM PRZELEWU LUB Z WYKORZYSTANIEM USŁUGI INICJOWANIA TRANSAKCJI PŁATNICZEJ}

Ponieważ historycznie możliwosć inicjowania i wykonywania elektronicznych transakcji płatniczych (płatności bezgotówkowych) możliwa była głównie za pośrednictwem banków (instytucji kredytowych), a więc podmiotów, których działalność jest ściśle regulowna i które podlegają ścisłemu nadzorowi, a ponadto

${ }^{13}$ Art. 4 ust. 2 UUP.

${ }^{14}$ Art. 3 ust. 3 UUP. Przy czym warto zwrócić uwagę, że definicja zawarta w art. 4 pkt 22 PSD2 jest nieco inna.

${ }^{15}$ Art. 3 ust. 4 UUP. 
traktowane były (i jak się wydaje nadal są) jako instytucje zaufania publicznego [Radziszewski 2013], w orzecznictwie SN przyjęto, że dla dochowania terminu do uiszczenia opłaty sądowej $\mathrm{w}$ formie bezgotówkowej decydująca jest data złożenia zlecenia płatniczego w banku (nie zaś data otrzymania środków przez sąd/data uznania rachunku właściwego sądu), wszakże pod warunkiem, że przelew w dniu jego przyjęcia przez bank lub najpózniej $\mathrm{w}$ terminie przewidzianym do uiszczenia opłaty miał dostateczne pokrycie pieniężne ${ }^{16}$. W jednym z postanowień SN dodał, że kwestia tego, czy i kto ponosi winę za brak pokrycia, może mieć znaczenie tylko dla przywrócenia uchybionego terminu [postanowienie SN z 27 stycznia 1969 r., I PZ 76/68]. Z kolei w niektórych postanowieniach SN zaznaczył, że złożenie bankowi polecenia przelewu przed upływem terminu do wniesienia opłaty sądowej może uzasadniać uznanie tego terminu za zachowany, o tyle tylko, o ile polecenie zostało rzeczywiście wykonane $^{17}$ (zasadność i konksekwencje tak określonego wymogu omówione zostały w rozdziale 0 ).

W uchwale SN z 25 czerwca 2003 r., III CZP 28/03, SN rozpatrywał sprawę, w której przelew zainicjowany został w banku zagranicznym. Przy czym chodziło o bank zagraniczny w rozumieniu ówcześnie obowiązujących przepisów ${ }^{18}$, a więc o bank z siedzibą za granicą, tj. w innym kraju niż Polska ${ }^{19}$. Obecnie przez bank zagraniczny rozumie się bank $\mathrm{z}$ siedzibą $\mathrm{w}$ państwie niebędącym państwem członkowskim Unii Europeskiej (UE) ${ }^{20}$. SN uznał wówczas, że zważywszy na fakt, że bank zagraniczny realizował dokonane przez stronę zlecenie przelewu za pośrednictwem banku krajowego (banku korespondenta), a więc w drodze polecenia rozliczeniowego (przy wykorzystaniu w tym celu tzw. komunikatu SWIFT, przekazywanego elektronicznie), należało uznać, że datą uiszczenia opłaty jest data otrzymania tego polecenia przez bank krajowy ${ }^{21}$. Omawianą

16 Postanowienie SN z 18 grudnia 2018 r...; postanowienie SN z 13 kwietnia 2018 r...; postanowienie SN z 25 stycznia 2017 r...; postanowienie SN z 24 czerwca 2015 r...; postanowienie SN z 21 stycznia 2015 r...; postanowienie SN z 21 listopada 2013 r...; postanowienie SN z 2 lutego 2011 r...; postanowienie SN z 19 czerwca 2008 r...; postanowienie SN z 22 kwietnia 2004 r...; postanowienie SN z 10 grudnia 2003 r...; uchwała SN z 25 czerwca 2003 r...; uchwała SN z 16 grudnia 1983 r...; postanowienie SN z 27 stycznia 1969 r...; postanowienie SN z 27 lutego 1962 r...; postanowienie SN z 27 listopada $1961 \mathrm{r} . .$.

${ }^{17}$ Postanowienie SN z 18 grudnia 2018 r...; postanowienie SN z 13 kwietnia 2018 r...; postanowienie SN z 2 lutego 2011 r...; postanowienie SN z 19 czerwca 2008 r....

${ }^{18}$ Art. 4 pkt 2 ustawy z dnia 29 sierpnia 1997 r...

${ }^{19}$ Uchwała SN z 25 czerwca 2003 r...

${ }^{20}$ Art. 4 ust. 1 pkt 2 p.b.

${ }^{21}$ Uchwała SN z 25 czerwca 2003 r... Chodzi o bank mający siedzibę na terytorium RP (zarówno na gruncie ówcześnie, jak i obecnie obowiązujących przepisów - art. 4 ust. 1 pkt 1 p.b.). $\mathrm{Z}$ treści omawianego orzeczenia nie wynika jednoznacznie jaka była rola banku korespondenta, $\mathrm{tj}$. czy osoba uiszczająca opłatę posiadała rachunek w tym banku, czy też w banku zagranicznym. Zarówno $\mathrm{w}$ scenariuszu $\mathrm{w}$ którym bank krajowy (bank korespondent) prowadziłby rachunek 
uchwałę należy uznać za zdezaktualizowaną, jeżeli chodzi o transakcje inicjowane u dostawców z siedzibą poza Polską, lecz mających siedzibę na obszarze UE. Wydaje się jednak, że nie przekreśla to jej oddziaływania mocą odpowiedniego stosowania na transakcje inicjowane u dostawców $\mathrm{z}$ siedzibą poza UE (np. transakcji inicjowanych w bankach zagranicznych w rozumieniu obenie obowiązujących przepisów). W takich wypadkach sądy raczej będą uznawać, że dniem uiszczenia opłaty sądowej będzie dzień otrzymania zlecenia lub środków przez pierwszego dostawcę mającego siedzibę na terenie UE.

W praktyce pojawiają się wątpliwości, czy jako datę uiszczenia opłaty sądowej można (należy) uznać dzień złożenia zlecenia płatniczego, gdy opłata uiszczana jest za pośrednictwem innego niż bank (instytucja kredytowa) dostawcy. Z aktualnego orzecznictwa SN wynika, że nie należy różnicować daty wniesienia przez stronę opłaty sądowej w zależności od tego, czy została ona przekazana za pomocą banku, czy instytucji płatniczej działającej na podstawie UUP $^{22}$, choć w przeszłości sytuacja ta oceniana była robieżnie ${ }^{23}$. Orzeczenia SN zapadły na kanwie spraw, w których sądy niższych instancji odrzuciły złożone przez stronę środki zaskarżenia z uwagi na to, że w dniu, w którym upływał termin na uiszczenie opłaty sądowej, nie doszło do uznania rachunku sądu, mimo, iż wcześniej złożone zostało zlecenie płatnicze. W glosie do postanowienia SN z dnia 21 stycznia 2015 r., IV CZ 96/14, J. Bodio słusznie wskazała, że strona, wnosząc opłatę w instytucji/placówce zajmującej się legalnie świadczeniem usług płatniczych, działa w dobrej wierze [Bodio 2015]. Jeżeli więc doszło do rzeczywistego wykonania polecenia strony (choćby złożone ono było w ostatnim dniu terminu wyznaczonego do uiszczenia opłaty), to - bez względu na datę jego wykonania - termin należy uznać za zachowany [Bodio 2015]. Podobnie SN

uiszczającego opłatę, otrzymując od banku zagranicznego jedynie zlecenie płatnicze (celem jego wykonania), jak również w scenariuszu, w którym bank korespondent nie prowadziłby rachunku, lecz jedynie otrzymałby środki tytułem opłaty sądowej (wraz ze zleceniem ich dalszego transferu), na gruncie analizowanego orzeczenia należałoby uznać, że opłatę uznaje się za uiszczoną z dniem otrzymania przez bank krajowy (bank korespondent) odpowiednio zlecenia lub środków, mimo, iż wówczas nie doszło jeszcze do uznania rachunku sądu.

${ }^{22}$ Postanowienie SN z 18 grudnia 2018 r...; postanowienie SN z 13 kwietnia 2018 r...; postanowienie SN z 25 stycznia 2017 r...; postanowienie SN z 21 stycznia 2015 r...; postanowienie SN z 19 września 2007 r....

${ }^{23} \mathrm{~W}$ postanowieniu z 18 grudnia 2018 r..., SN wskazał, że przeważa pogląd, że w takiej sytuacji dniem wniesienia odpowiedniej opłaty sądowej jest dzień uznania nią rachunku bankowego właściwego sądu, a nie dzień przekazania odpowiednich funduszy tej instytucji (postanowienie SN z 19 września 2013 r...; postanowienie SN z 20 lutego 2015 r...; postanowienie SN z 26 września 2008 r...; postanowienie SN z 10 czerwca 2005 r...; postanowienie SN z 30 czerwca 2005 r... oraz postanowienie SN z 27 października 2004 r...). Jednocześnie SN dostrzegł, że w części orzeczeń stwierdza się że nie należy różnicować daty wniesienia przez stronę opłaty sądowej w zależności od tego, czy została ona przekazana za pomocą banku, czy instytucji płatniczej działającej na podstawie UUP (postanowienie SN z 21 stycznia 2015 r...; postanowienie SN z 19 września 2007 r...). 
w postanowieniu 18 grudnia 2018 r., IV CZ 68/18 podkreslił, że brak precyzyjnego uregulowania sposobu dokonywania opłat przez wskazanie instytucji, w których wyłącznie można uiszczać opłaty sądowe, nie pozwala na wyprowadzanie dla strony negatywnych skutków prawnych z dokonania wpłaty w placówce niebędącej bankiem, lecz zajmującej się legalnie realizowaniem przelewów. Analogiczne stanowisko zaprezentował również NSA w uchwale 7 sędziów NSA z 22 stycznia 2018 r., I FPS 3/17, LEX nr 24281997. NSA uznał, że w przypadku uiszczania opłaty sądowej na rachunek bankowy właściwego sądu administracyjnego, stosownie do art. $219 \S 2$ zd 1 p.p.s.a za pośrednictwem krajowej instytucji płatniczej w rozumieniu UUP, dzień przekazania środków pieniężnych tej instytucji lub jej agentowi jest równoznaczny z dniem uiszczenia opłaty, o ile doszło do uznania rachunku bankowego sądu należną kwotą ${ }^{24}$. NSA uzasadnił swoje rozstrzygnięcie koniecznością zagwarantowania jednostce konstytucyjnego prawa do sądu na dostatecznie jasnych i porównywalnych warunkach. Ponadto, przyjęcie odmiennego poglądu prowadziłoby - jak słusznie podkreslił NSA - do naruszenia konstytucyjnej zasady równości wobec krajowych instytucji płatniczych.

Poglądy SN i NSA należy uznać za wszech miar słuszne. Uwzględniają one kontekst unijny i okoliczność, że obecnie świadczenie usług płatniczych w krajach UE regulowane jest na podstawie legislacji krajowych stanowiących implementację PSD2. Zarazem, orzeczenia te powinny być ujmowane szeroko, jako odnoszące się do wszystkich dostawców i wszelkich świadczonych przez nie usług płatnicych prowadzących do transferu środków pieniężnych na rzecz sądu (prowadzących do uznania rachunku płatniczego u dostawcy sądu), tj. wykonywanie transakcji płatniczych ${ }^{25}$, w tym przekaz pieniężny ${ }^{26}$ czy usługa inicjowania transakcji płatniczej ${ }^{27}$ (dalej również: PIS). Szczególnego komentarza wymaga ostatnia $\mathrm{z}$ wymienionych usług. Została ona wprowadzona do UUP w wyniku implementacji PSD2 i polega na zainicjowaniu zlecenia płatniczego przez dostawcę świadczącego usługę inicjowania transakcji płatniczeje ${ }^{28}$ (dalej również: PISP) na wniosek użytkownika $\mathrm{z}$ rachunku płatniczego tego użytkownika prowadzonego przez innego dostawcę ${ }^{29}$ (tj. przez dostawcę prowadzącego rachunek ${ }^{30}$ ). PISP $\mathrm{w}$ zakresie, w jakim świadczy tę usługę, nie

24 Ibidem.

25 Art. 3 ust. 1 pkt 2 lit b i c UUP (wydaje się, że de lega lata trudno będzie uiścić opłatę sądową z wykorzystaniem usługi polecenia zapłaty [art. 3 ust. 1 pkt 2 lit a UUP]. Nie sposób natomiast wykluczyć możliwości uiszczenia opłaty sądowej z wykorzystaniem karty płatniczej akceptowanej przez agenta rozliczeniowego [art. 3 ust. 1 pkt 5 UUP].

${ }^{26}$ Art. 3 ust. 1 pkt 6 UUP.

27 Art. 3 ust. 1 pkt 7 UUP.

28 Art. 2 pkt 4d UUP.

${ }^{29}$ Art. 3 ust. 5 UUP.

${ }^{30}$ Art. 2 pkt 4c UUP. 
dokonuje transferu środków (dokonuje go dostawca prowadzący rachunek $\mathrm{i}$ ewentualnie inne podmioty zangażowane $\mathrm{w}$ wykonanie transakcji) ${ }^{31}$. Mimo że rolą PISP jest wyłącznie przyjęcie zlecenia platniczego płatnika ${ }^{32}$ i zainicjowanie zlecenia płatniczego ${ }^{33}$ (transakcji płatniczej), nie ma żadnego istotnego argumentu, który uzsadniałby przyjęcie, że datą uiszczenia opłaty inicjowanej z wykorzystaniem usługi PIS, może być jakakolwiek inna data, aniżeli dzień złożenia zlecenia płatniczego ${ }^{34}$ (wniosku $^{35}$ ) przez płatnika do PISP - oczywiście pod warunkiem, że płatnik ma pokrycie na rachunku, który ma zostać obciążany wskutek zainicjowania transakcji przez PISP (a który prowadzony jest przez innego dostawcę, tj. dostawcę prowadzącego rachunek) i że transkacja zostanie wykonana (z zastrzeżeniem uwag poczynionych w rozdziale 4).

Odnosząc się do katalogu podmiotów, które mogą przyjmować zlecenie lub środki, po pierwsze, należy pamiętać, że dostawcy mogą prowadzić działalność za pośrednictwem agentów i insourcerów. Uiszczenie opłaty za pośrednictwem tych podmiotów powinno być traktowane jak jej uiszczenie za pośrednictwem samego dostawcy ${ }^{36}$. Po drugie, wśród podmiotów mających status dostawcy znajdują się zarówno podmioty $\mathrm{z}$ siedzibą $\mathrm{w}$ Polsce, jak również podmioty $\mathrm{z}$ siedzibą $\mathrm{w}$ innym niż Polska państwie. Wynika to $\mathrm{z}$ faktu, że zgodnie z obowiązującą na rynku finansowym zasadą jednolitego paszportu, niektórzy dostawcy moga - po przeprowadzeniu odpowiedniej procedury notyfikacyjnej - prowadzić działalność w innych krajach członkowskich przez oddział, w ramach działalności transgranicznej lub za pośrednictwem agenta, w zakresie wynikającym z zezwolenia wydanego przez właściwe organy nadzorcze ${ }^{37}$.

Należy zatem przyjąć, że datą uiszczenia opłaty sądowej będzie dzień złożenia zlecenia płatniczego (lub przekazania środków) każdemu podmiotowi mającemu status dostawcy, niezależnie od tego, czy ma on siedzibę w Polsce, czy też w innym państwie UE i niezależnie od tego, czy płatnik posiada rachunek u takiego dostawy, oczywiście pod warunkiem, że transakcja ma pokrycie i zostanie wykonana (z zastrzeżeniem uwag poczynionych $\mathrm{w}$ rozdziale 4 ). Takie

${ }^{31}$ Zresztą PISP z założenia nie mogą wchodzić w posiadanie środków użytkowników [art. 59r ust. 3 pkt 1 UUP].

${ }^{32}$ Art. 59 q ust. 1 in principio oraz ust. 2 UUP, gdzie mowa jest o składaniu zlecenia płatniczego PISP. W art. 46 in prinicpio PSD2 mowa jest o inicjowaniu zlecenia płatniczego za pośrednictwem PISP.

${ }^{33}$ Art. 3 ust. 5 UUP.

${ }^{34}$ Art. 59q ust. 1 in principio oraz ust. 2 UUP.

${ }^{35}$ Art. 3 ust. 5 UUP.

${ }^{36}$ Tak uznał NSA w uchwale 7 sędziów NSA z 22 stycznia 2018 r... w odniesieniu do agenta krajowej instytucji płatniczej. Z kolei w wyroku SO w Siedlcach z 5 lipca 2019 r..., sąd ten stwierdził, że ubezpieczona dochowała terminu opłacenia składki na dobrowolne ubezpieczenie chorobowe, gdyż dokonała wpłaty w placówce podmiotu działającego w imieniu i na rzecz krajowej instytucji płatniczej, tj. zgodnie z art. 86 ust. 1 UUP.

${ }^{37}$ Zob. np. art. 92-98b, 132x i 132y UUP. 
podejście koreluje również z wynikającą z art. 54 ust. 1 UUP zasadą, zgodnie z którą termin realizacji transakcji rozpoczyna się $\mathrm{w}$ dniu, w którym dostawca płatnika otrzymał zlecenie płatnicze [Grabowski 2020, komentarz do art. 54, pkt 4]. Warto podkreslić, że przepis ten znajduje zastosowanie również do należności podatkowych ${ }^{38}$ (które mają charakter daniny publicznej). Co więcej, w przypadku niedotrzymania terminu wykonania transakcji płatniczej $\mathrm{w}$ zakresie takiej należności, ustawodawca wprowadza odpowiedzialność dostawcy (obowiązek uiszczenia odsetek podatkowych za zwłokę), z czego prima facie można by wywodzić, że uznaje, iż samo zlecenie wykonania transakcji oznacza brak uchybienia terminowi zapłaty podatku. Tymczasem Ordynacja Podatkowa [Ustawa z dnia 29 sierpnia 1997 r. - Ordynacja podatkowa, Dz.U. 1997, nr 137, poz. $926 \mathrm{ze} \mathrm{zm}$.] stanowi, że w obrocie bezgotówkowym za termin dokonania zapłaty podatku uważa się dzień obciążenia rachunku podatnika w banku, SKOK, instytucji płatniczej, małej instytucji płatniczej lub instytucji pieniądza elektronicznego na podstawie polecenia przelewu, a w przypadku zapłaty za pomocą instrumentu płatniczego dzień uzyskania potwierdzenia autoryzacji transakcji ${ }^{39}$. Nie jest zatem tym dniem, często w praktyce wskazywany przez podatników, dzień zlecenia bankowi (kasie) dokonania tej operacji ani też dzień, kiedy pieniądze trafią na rachunek organu podatkowego [Etel 2013, komentarz do art. 60, pkt 2]. Z kolei w przypadku polecenia przelewu $\mathrm{z}$ rachunku podatnika w banku, instytucji kredytowej, unijnej instytucji płatniczej lub unijnej instytucji pieniądza elektronicznego, niemających siedziby lub oddziału na terytorium RP za termin zapłaty podatku uważa się dzień złożenia zlecenia płatniczego przez podatnika, jeżeli wpłacana kwota zostanie uznana na rachunku bankowym organu podatkowego $\mathrm{w}$ terminie wskazanym $\mathrm{w}$ art. 54 UUP (przy czym, w razie przekroczenia tego terminu za termin zapłaty uważa się dzień uznania kwoty na rachunku bankowym organu podatkowego $)^{40}$.

\section{UISZCZENIE OPŁATY SĄDOWEJ PRZEKAZEM POCZTOWYM}

Również na tle płatności gotówkowych wnoszonych w polskiej placówce pocztowej operatora wyznaczonego ${ }^{41}$ (aktualnie Poczta Polska S.A. ${ }^{42}$ ) w orzecznictwie SN ugruntował się pogląd, że w takim wypadku datą uiszczenia opłaty sądowej na rachunek bankowy sądu jest data przyjęcia tej opłaty przez

\footnotetext{
${ }^{38}$ Art. 55 ust. 1 UUP (rozumowanie a contrario).

${ }^{39}$ Art. $60 § 1$ pkt 2 Ordynacji Podatkowej.

${ }^{40}$ Art. 60 §1 a Ordynacji Podatkowej.

${ }^{41}$ Art. 3 pkt 13 p.p. [Ustawa $\mathrm{z}$ dnia 23 listopada 2012 r...].

${ }^{42}$ Zob. art. 71 ust. 1 p.p. oraz decyzja Prezes Urzędu Komunikacji Elektronicznej Magdaleny
} Gaj z 30 czerwca 2015 r... 
operatora $^{43}$ (analogiczne rozwiązanie przewidziane jest w art. $60 \S 1$ pkt 1 Ordynacji Podatkowej). SN potwierdził takie stanowisko w uchwale z 26 lutego 2014 r., III CZP 112/13, wskazując, że działalność Poczty Polskiej S.A. jako operatora wyznaczonego jest traktowana i postrzegana - w odróżnieniu od innych operatorów - jak działalność noszącą znamiona urzędowe. Wreszcie SN stwierdził, że Poczta Polska S.A. wciąż zachowuje status instytucji zaufania publicznego, także w zakresie świadczenia usług finansowych, co wynika nie tylko z jej renomy utrwalanej w świadomości społecznej przez wiele lat, ale także z tego, że - zapewne również ze względu na tę renomę - powierzono jej odpowiedzialną funkcję pocztowego operatora wyznaczonego ${ }^{44}$. Co istotne, uchwała SN z 26 lutego 2014 r., III CZP 112/13 odnosiła się do usługi polegającej na przyjęciu przez operatora wyznaczonego wpłaty gotówkowej w celu przekazania jej na wskazany rachunek bankowy ${ }^{45}$. Z uzasadnienia uchwały można wywieść, że w ocenie SN usługi takiej nie należy kwalifikować jako przekazu pocztowego, który polega na przyjęciu gotówki i przekazaniu jej adresatowi ${ }^{46}$. Jest to o tyle ciekawe, że w omawianej uchwale SN przywołał m.in. uchwałę SN z 21 stycznia 2011 r., III CZP 115/10. W uchwale z 2011 r. SN uznał, że datą uiszczenia opłaty sądowej klasycznym przekazem pocztowym realizowanym za pośrednictwem operatora publicznego świadczącego powszechne usługi pocztowe jest data nadania przekazu potwierdzona przez operatora ${ }^{47}$. Zarazem stwierdził, że od działalności „Poczty Polskiej”, jako operatora publicznego, należało oddzielić jej działalność gospodarczą

${ }^{43}$ Uchwała SN z 26 lutego 2014 r...; uchwała SN z 21 stycznia 2011 r...; postanowienie SN z 27 lutego 1962 r...

${ }^{44}$ Uchwała SN z 26 lutego 2014 r...

${ }^{45} \mathrm{SN}$ wskazał, że usługa ta polega na tym, że operator ten przyjmuje wpłatę określonej kwoty w gotówce, a następnie kwotą tą uznawany jest rachunek bankowy wskazany przez wpłacającego. Zgodnie z § 3 pkt 10 Regulaminu świadczenia usługi finansowej przyjmowania wpłat na rachunki bankowe w Poczcie Polskiej S.A. w obrocie krajowym obowiązującym od 20 grudnia 2018 roku: „wpłata gotówkowa przyjmowana w placówce pocztowej albo przez listonoszy i przekazywana do banku prowadzącego rachunek bankowy odbiorcy".

${ }^{46} \mathrm{SN}$ wskazał, że nie zdefiniowano, choćby przez określenie ramowych cech konstrukcyjnych, usługi polegającej na przyjęciu przez operatora wpłaty gotówkowej w celu przekazania jej na wskazany rachunek bankowy. W ocenie SN czynność ta nie mieści się w katalogu usług pocztowych ustanowionym w art. 2 ust. 1 pkt 1-5 p.p. w związku z czym w odniesieniu do Poczty Polskiej S.A. należy ją zaliczyć do grupy usług finansowych, które mogą być przedmiotem jej działalności gospodarczej (por. art. 12 ust. 1 pkt 4 u.k.P.P.) - uchwała SN z 26 lutego 2014 r...

${ }^{47}$ Uchwała SN z 21 stycznia 2011 r... SN wskazał, że istotą przekazu pocztowego jest wypłacenie (doręczenie) adresatowi - na polecenie nadawcy - określonej kwoty pieniężnej w gotówce, przekaz zatem mieści się w użytym w $\S 2$ - nieobowiązującego obecnie - rozporządzenia Ministra Sprawiedliwości w sprawie sposobu uiszczania opłat sądowych w sprawach cywilnych z 2006 r., szeroko rozumianym pojęciu „,wpłata gotówkowa”. Kierując się ochroną interesów stron postępowania należałoby przyjąć analogiczną wykładnię na gruncie $\S 2$ pkt 2 rozporządzenia MS, aczkolwiek w obu wspomnianych aktach mowa jest o „wpłacie gotówkowej bezpośrednio w kasie właściwego sądu", w związku z czym przynajmniej na gruncie literalnego brzmienia tych przepisów taki wniosek wcale nie jest oczywisty. 
w postaci pośrednictwa w wykonywaniu usług finansowych (art. 12 ust. 1 pkt 4 i 5 u.k.P.P. [Ustawa z dnia 5 września 2008 r. o komercjalizacji państwowego przedsiębiorstwa użyteczności publicznej „Poczta Polska”, Dz.U. 2008, nr 180, poz. 1109 ze zm.] $)^{48}$. Wydaje się, że w ocenie SN działalność ta obejmuje również słuigę polegającą na przyjęciu przez operatora wyznaczonego wpłaty gotówkowej w celu przekazania jej na wskazany rachunek bankowy. W ocenie SN na tym polu „Poczta Polska” nie działała jako operator publiczny, lecz jako „zwykły” przedsiębiorca, w związku z czym nie mogły mieć do niej w tym zakresie zastosowania przepisy wspomnianej ustawy ani ustanawiane przez ustawodawcę domniemania $^{49}$. SN poszedł zresztą o krok dalej, przyjmując analogiczne stanowisko w odniesieniu do innych przedsiębiorców zajmujących się działalnością polegającą na transferze pieniędzy, np. operatorów prywatnych, parabanków lub instytucji doręczeniowych ${ }^{50}$.

Obecnie jedną z usług pocztowych stanowi realizowanie przekazów pocztowych $^{51}$. Prawo pocztowe definiuje tę usługę jako polecenie doręczenia adresatowi określonej kwoty pieniężnej przez operatora pocztowego ${ }^{52}$. Nie jest jednak do końca jasne, czy chodzi wyłącznie o klasyczne doręczenie odbiorcy gotówki (jak przyjął SN we wspomnianej wyżej uchwale z 26 lutego 2014 r., III CZP 112/13 przekaz pocztowy sensu stricto), czy też usługę polegającą na przyjęciu gotówki od płatnika w celu dokonania wpłaty (w istocie przelewu) środków na rachunek płatniczy odbiorcy (co można by określić mianem przekazu pocztowego sensu largo $^{53}$ ). Dodatkowo, UUP stanowi, że do transakcji płatniczych opartych na przekazie pocztowym w rozumieniu aktów Światowego Związku Pocztowego w postaci papierowej, wystawionych na dostawcę w celu postawienia środków pieniężnych do dyspozycji odbiorcy stosuje się wyłącznie przepisy UUP wskazane $\mathrm{w}$ art. $6 \mathrm{a}$ tej ustawy ${ }^{54}$. Z kolei zgodnie $\mathrm{z}$ u.k.P.P., przedmiotem działalności gospodarczej Poczty Polskiej S.A. jest m.in. świadczenie usług finansowych i wykonywanie czynności z nimi związanych ${ }^{55}$, a także pośrednictwo w wykonywaniu

${ }^{48}$ Ibidem.

${ }^{49}$ Ibidem.

${ }^{50}$ Ibidem. W tym zakresie SN przywołał: postanowienie SN z 10 czerwca 2005 r... i postanowienie SN z 26 września 2008 r...

${ }^{51}$ Art. 2 ust. 1 pkt 5 p.p.

${ }^{52}$ Art. 3 pkt 16 p.p.

${ }^{53} \mathrm{~W}$ tym kontekście warto zwrócić uwagę, że zgodnie z art. 3 ust. 3 UUP, usługa przekazu pieniężnego oznacza usługę płatniczą świadczoną bez pośrednictwa rachunku płatniczego prowadzonego dla płatnika, polegającą na transferze do odbiorcy lub do innego dostawcy przyjmującego środki pieniężne dla odbiorcy środków pieniężnych otrzymanych od płatnika lub polegającą na przyjęciu środków pieniężnych dla odbiorcy i ich udostępnieniu odbiorcy. Usługa przyjęcia gotówki i doprowadzenia do uznania rachunku odbiorcy stanowi więc jeden z możliwych rodzajów przekazu pieniężnego.

${ }^{54}$ Art. 6 pkt 7 lit g w zw. z art. 6a UUP.

${ }^{55}$ Art. 12 ust. 1 pkt 4 u.k.P.P. 
usług finansowych, w tym czynności bankowych ${ }^{56}$. Istotnie, w świetle p.p. czynności te nie zostały określone jako usługi pocztowe ${ }^{57}$. Należy jednak zwrócić uwagę, że zgodnie z art. 4 ust. 2 pkt 5 UUP, zarówno Poczta Polska S.A. w zakresie, w jakim odrębne przepisy upoważniają ją do świadczenia usług płatniczych, jak również oddział podmiotu świadczącego w innym niż RP państwie członkowskim, zgodnie z prawem tego państwa, pocztowe usługi platnicze, uprawnionego zgodnie z prawem tego państwa do świadczenia usług płatniczych, mają status dostawcy $^{58}$. Należy przyjąć, że w przypadku Poczty Polskiej S.A. szczególnymi przepisami, o których mowa we wspomnianym przepisie UUP, są zarówno przepisy p.p., jak i u.k.P.P. Oznacza to, że Poczta Polska S.A. w zakresie w jakim świadczy usługi płatnicze powinna być traktowana jako dostawca. Obejmuje to zarówno klasyczny przekaz pocztowy, jak również usługę przyjęcia gotówki celem przekazania środków na rachunek odbiorcy. Bardziej problematyczna jest kwestia operatorów pocztowych z innych niż Polska krajów członkowskich. Wówczas determinujące znaczenie dla ustalenia, czy taki podmiot ma prawo świadczyć usługi płatnicze (a w rezultacie, czy ma status dostawcy) ma prawo państwa pochodzenia tego podmiotu.

\section{WYKONANIE TRANSAKCJI PŁATNICZEJ JAKO PRZESŁANKA DOCHOWANIA TERMINU NA UISZCZENIE OPŁATY SĄDOWEJ}

W orzecznictwie przyjmuje się, że dla dochowania terminu do uiszczenia opłaty sądowej w formie bezgotówkowej decydująca jest data zlecenia płatniczego, ale tylko wówczas, gdy w dniu jego przyjęcia przez dostawcę lub w terminie przewidzianym do uiszczenia opłaty transakcja miała dostateczne pokrycie pieniężne na rachunku, a ponadto transakcja została rzeczywiście dokonana ${ }^{59}$. Bezwarunkowa akceptacja tej ostatniej - prima facie ze wszech miar uzasadnionej - przesłanki, oznaczałaby jednak, że w konkretnych okolicznościach ryzyko terminowego uiszczenia opłaty sądowej ponosiłby użytkownik, mimo iż zlecił transakcję z zachowaniem wymaganego prawem terminu, zarazem dysponując niezbędnymi $w$ tym celu środkami. Tymczasem dochowanie terminu uiszczenia opłaty przez stronę nie powinno zależeć od okoliczności przypadkowych, od strony niezależnych ${ }^{60}$.

${ }^{56}$ Art. 12 ust. 1 pkt 5 u.k.P.P.

${ }^{57}$ Co więcej, ani przekaz pocztowy, ani też usługi finansowe, czy pośrednictwo w wykonywaniu usług finansowych nie stanowią usługi wchodzącej w zakres usług powszechnych [art. 3 pkt 30 p.p.].

${ }^{58}$ Zob. też art. 4 ust. $2 b$ pkt 2 UUP.

${ }^{59}$ Postanowienie SN z 18 grudnia 2018 r...; postanowienie SN z 13 kwietnia 2018 r...; postanowienie SN z 2 lutego 2011 r...; postanowienie SN z 19 czerwca 2008 r...

${ }^{60} \mathrm{Z}$ treści uchwały SN z 26 lutego 2014 r... można wywieść, że w ocenie SN dochowanie terminu uiszczenia opłaty przez stronę nie powinno zależeć od okoliczności przypadkowych, na 
Zgodnie z art. 144 ust. 1 i 2 UUP, jeżeli dostawca płatnika ponosi odpowiedzialność za niewykonanie lub nienależyte wykonanie transakcji, niezwłocznie zwraca płatnikowi kwotę takiej transakcji albo, w przypadku, gdy płatnik korzysta z rachunku płatniczego, przywraca obciążony rachunek płatniczy do stanu, jaki istniałby, gdyby nie miało miejsca niewykonanie lub nienależyte wykonanie transakcji ${ }^{61}$. Przyjęta regulacja nie zawsze zapewni pełną ochronę interesów płatnika, co wyraźnie widać na przykładzie niewykonania lub nienależytego wykonania transakcji, której celem było uiszczenie opłaty sądowej. W takim wypadku przywrócenie obciążonego rachunku płatnika do stanu, jaki istniałby, gdyby nie miało miejsca nienależyte wykonanie transakcji płatniczej okaże się dla płatnika niewystarczające. Płatnik odzyska co prawda swoje środki, nie dojdzie jednak do uznania rachunku sądu, w związku z czym płatnik poniósłby negatywne skutki na gruncie postępowania sądowego. Wówczas płatnik powinien skierować do dostawcy reklamację ${ }^{62}$, a niezależnie od tego na podstawie art. $169 \S 1-3$ k.p.c., skierować do sądu pismo z wnioskiem o przywrócenie terminu ${ }^{63}$ wraz z dowodem powtórnego uiszczenia opłaty (nawet jeżeli w tym wypadku zlecenie miałoby zostać złożone po upływie terminu na uiszczenie opłaty). W przypadku uwzględnienia reklamacji dostawca powinien doprowadzić do należytego wykonania transakcji, zgodnie z pierwotnym zleceniem (złożonym przed upływem terminu na wniesienie opłaty). Dokumenty wynikające $\mathrm{z}$ postępowania reklamacyjnego strona powinna przedłożyć sądowi, aby udowodnić (a przynajmniej uprawdopodobnić) brak swojej winy w niewykonanej lub nienależycie wykonanej transakcji (a w efekcie w uchybieniu terminu na uiszczenie opłaty). Należałoby uznać, że terminem uiszczenia opłaty będzie data pierwotnego zlecenia płatniczego (tego, które pierwotnie nie zostało należycie wykonane przez

które strona nie ma wpływu, a w szczególności od ustalonej przez operatora wyznaczonego metody wykonywania usług polegających na przyjmowaniu wpłaty gotówkowej w celu przekazania jej na wskazany rachunek bankowy (które to metody te mogą być różne i podlegać zmianom).

${ }^{61}$ Przy czym w przypadku niewykonania transakcji w zasadzie brak jest podstaw do zwrotu kwoty transakcji, czy też przywrócenia do wcześniejszego stanu, gdyż fakt jej niewykonania, powoduje, że nie doszło do żadnej zmiany. W tym wypadku należy uznać, że płatnikowi nie przysługuje roszczenie o przywrócenie pierwotnego stanu rachunku. Przysługiwać będzie natomiast roszczenie o wykonanie transakcji zgodnie ze zleceniem i ewentualnie odszkodowania za wyrządzoną szkodę na zasadach ogólnych.

${ }^{62}$ Art. 2 pkt 24, 15a i 15 b UUP.

${ }^{63}$ Analogicznie jak w przypadku kwestii winy za brak pokrycia inicjowanej transakcji [postanowienie SN z 27 stycznia 1969 r...]. Nie jest jednak oczywiste kiedy w takim wypadku dochodzi do ustania przyczyny uchybienia terminu, od którego to momentu liczony jest tygodniowy termin na złożenie pisma $\mathrm{z}$ wnioskiem o przywrócenie terminu (osoba uiszczająca opłatę nie ma wiedzy ani o tym kiedy transakcja zostanie wykonana, ani kiedy dochodzi do uznania rachunku sądu - zresztą przez długi czas w ogóle może nie wiedzieć, że nie doszło do wykonania transakcji lub, że doszło do nienależytego wykonania transakcji w związku z czym z perspektywy sądu opłata nie została uiszczona). 
dostawcę), pod warunkiem, że ostatecznie opłata została uiszczona, a więc doszło do uznania rachunku sądu. Nie powinno być istotne, czy do uznania rachunku doszło wskutek pozytywnego rozpatrzenia reklamacji klienta (a zatem w istocie do wykonania pierwotnego zlecenia płatniczego), czy też wskutek wykonania powtórnego zlecenia płatniczego złożonego przez płatnika już po upływie terminu na uiszczenie opłaty, jeżeli pierwotne zlecenie (złożone przed upływem terminu) złożone zostało prawidłowo, rachunek mial odpowiednie pokrycie, a za niewykonanie lub nienależyte wykonane transkcji odpowiedzialności/winy nie ponosi płatnik ${ }^{64}$ (w drugim wypadku można rozważać, czy nie powinno dojść do przywrócenia przez sąd terminu na uiszczenie opłaty). Przyjęcie odmiennego stanowiska prowadziłoby do wniosku, że w rzeczywistości to uiszczający opłatę ponosi ryzyko niewykonania bądź nienależytego wykonania transakcji przez dostawcę. Tymczasem, na gruncie UUP, w przypadku transakcji inicjowanych przez płatnika, zasadniczo to właśnie dostawca odpowiada za całkowitą kwotę transakcji i czas jej wykonania, jak również pełną odpowiedzialność za wszelkie uchybienia innych stron uczestniczcych w kolejnych etapach łańcucha płatności (cyklu rozliczniowego), aż do odbiorcy [Czech 2012: 110] ${ }^{65}$ - przyjmuje się, że jest to odpowiedzialność oparta na zasadzie ryzyka [Bajor 2017, komentarz do art. 144]. W tym kontekście negatywnej oceny wymaga rozwiązanie przyjęte w art. $60 \S 1$ pkt 2 Ordynacji Podatkowej, które termin zapłaty podatku uzależnia od dnia obciążenia rachunku podatnika (co nie jest zadarzeniem, na które podatnik ma bezpośredni wpływ), nie zaś od dnia złożenia zlecenia płatniczego. Tymczasembrak obciążenia rachunku może wynikać z przyczyn przez podatnika niezależnych i niezawinionych.

Zasadniczo nakreślony problem może się pojawić tylko wówczas, gdy dostawca płatnika (dostawca osoby uiszczającej opłatę sądową) i dostawca odbiorcy (dostawca sądu) są różnymi podmiotami, a dostawca płatnika nie doprowadzi do uznania rachunku dostawcy odbiorcy ${ }^{66}$. Od momentu, w którym rachunek dostawcy odbiorcy został uznany, to własnie ten podmiot ponosi odpowiedzialność wobec odbiorcy za niewykonanie lub nienależyte wykonanie

${ }^{64}$ Odpowiedzialność mógł ponosić dostawca, ale do niewykonania lub nienależytego wykonania transakcji mogło dojść przykładowo wskutek siły wyższej (a w takim wypadku odpowiedzialność dostawcy jest wyłączona na podstawie art. 149 UUP).

${ }^{65}$ Art. 144 ust. $1-2$ UUP. Aczkolwiek należy mieć na uwadze, że zgodnie z art. 144 ust. 3 UUP, jeżeli rachunek dostawcy odbiorcy został uznany zgodnie $\mathrm{z}$ art. 54, dostawca odbiorcy ponosi odpowiedzialność wobec odbiorcy za niewykonanie lub nienależyte wykonanie transakcji płatniczej.

${ }^{66}$ Art. 54 UUP. Analogiczny problem może się pojawić w przypadku przekazu pieniężnego oraz przekazu pocztowego i to w dwóch wariantach każdej z tych usług, a więc w sytuacji w której płatnik przekazuje gotówkę i ta przekazywana jest do kasy sądu, jak również gdy dostawca przekazuje środki na rachunek sądu. W przypadku niewykonania lub nienależytego wykonania transakcji przez któregokolwiek z dostawców biorących udział w łańcuchu płatności, strona uiszczająca opłatę nie powinna ponosić negatywnych skutków procesowych z tego tytułu. 
transakcji płatniczej ${ }^{67}$. Jeżeli dostawca odbiorcy ponosi taką odpowiedzialność, obowiązany jest niezwłocznie przekazać do dyspozycji odbiorcy kwotę transakcji płatniczej albo, w przypadku, gdy odbiorca korzysta $\mathrm{z}$ rachunku płatniczego, obowiązany jest uznać rachunek płatniczy odbiorcy odpowiednią kwotą w celu doprowadzenia rachunku płatniczego do stanu, jaki istniałby, gdyby nie miało miejsca niewykonanie lub nienależyte wykonanie transakcji płatniczej ${ }^{68}$. W tym wypadku regulacja UUP zapewnia więc ochronę praw i interesów osoby uiszczającej opłatę w tym sensie, że w przypadku niewykonania lub nienależytego wykonania transakcji przez dostawcę odbiorcy, finalnie powinien on doprowadzić do uznania rachunku sądu. Będzie tak również w sytuacji, gdy dostawca płatnika jest zarazem dostawcą odbiorcy. Wówczas nie ma jednak konieczności doprowadzenia do uznania rachunku dostawcy odbiorcy (gdyż dostawca płatnika jest zarazem dostawcą odbiorcy), a zatem ten sam dostawca ponosić będzie wobec odbiorcy odpowiedzialność za należyte wykonanie transakcji. Aczkolwiek należy podkreślić, że odpowiedzialność dostawcy odbiorcy wobec odbiorcy występuje wyłączenie $\mathrm{w}$ relacji $\mathrm{z}$ odbiorcą (roszczenia przysługują odbiorcy), w związku $\mathrm{z}$ czym $\mathrm{w}$ tym zakresie uprawnienia płatnika są ograniczone ( $\mathrm{w}$ istocie to sąd powien dochodzić swojego roszczenia o uznanie rachunku kwotą należną z tytułu opłaty sądowej).

\section{PODSUMOWANIE}

Przyjęty w aktualnym orzecznictwie SN i NSA kierunek wykładni przepisów regulujących zasady uiszczania opłat w postępowaniu cywilnym i sądowo-administracyjnym należy ocenić pozytywnie. Datą uiszczenia opłaty sądowej powinien być dzień złożenia zlecenia płatniczego (przekazania środków) dowolnemu dostawcy w rozumieniu UUP (co obejmuje dostawców z siedzibą w Polsce, jak również dostawców $\mathrm{z}$ siedzibą w innych państwach członkowksich UE), a także oddziałom, agentom oraz insourcerom tych dostawców. Honorowana powinna być każda usługa prowadząca do uznania rachunku sądu (przelew, PIS, przekaz prowadzący do uznania rachunku sądu), jak również prowadząca do otrzymania przez sąd gotówki (klasyczny przekaz pieniężny lub pocztowy). Wykonywana transakcja powinna mieć pokrycie pieniężne, niemniej niewykonanie lub nienależyte wykonanie transakcji niezawinione przez podmiot uiszczający opłatę, nie powinny jej obciążać negatywnymi skutkami na gruncie postępowania sądowego. Przyjęcie innego poglądu oznaczałoby, że to osoba uiszczająca opłatę ponosi ryzyko niewykonania lub nienależytego wykonania transakcji, co jest wnioskiem trudnym do zaakceptowania i skutkowałoby niedopuszczalnym ograniczeniem prawa do sądu $\mathrm{w}$ sytuacji, w której płatnik złożył zlecenie płatnicze celem

${ }^{67}$ Art. 144 ust. 3 UUP.

${ }^{68}$ Art. 144 ust. 4 UUP. 
uiszczenia opłaty sądowej. Dodatkowo, bezpodstawnie różnicowałoby sytuację stron uiszczających opłaty za pośrednictwem wybranych dostawców oraz sytuację samych dostawców, prowadząc do dyskryminacyjnego traktowania części z nich i zaburzania konkurencyjności rynku usług płatniczych. Niewykonanie lub nienależyte wykonanie transakcji, w tym kwestia tego, czy i kto ponosi winę za brak jej pokrycia pieniężnego, mogą również uzasadniać przywrócenie uchybionego przez stronę terminu na uiszczenie opłaty sądowej. De lege ferenda pożądane jest precyzyjne uregulowanie omawianej kwestii w odpowiednich aktach normatywnych (czy to na poziomie ustawy czy też rozporządzenia). Pożądane może się okazać przyjęcie analogicznych rozwiązań na gruncie przepisów o daninach publicznych, w tym w szczególności Ordynacji Podatkowej.

\section{BIBLIOGRAFIA}

Bajor B., 2017, [w:] Ustawa o ustugach płatniczych. Komentarz, Bajor B., Byrski., Zalcewicz A., wydanie II, Wolters Kluwer.

Balkowski R., 2018, Bezpieczeństwo systemów teleinformatycznych - zmiany, trendy $i$ zasady Poradnik klienta ustug finansowych, KNF, Warszawa.

Bodio J., 2015, Postępowanie cywilne - koszty sadowe - uiszczenie opłaty sadowej za pośrednictwem instytucji płatniczej świadczacej ustugi na podstawie ustawy z 19 sierpnia 2011 r. Glosa do postanowienia SN z dnia 21 stycznia 2015 r., IV CZ 96/14, „Orzecznictwo Sądów Polskich”, nr 12.

Czech T., 2012, Termin wykonania transakcji platniczej $i$ data waluty, „Monitor Prawa Bankowego", nr 7-8 (20-21).

Decyzja Prezes Urzędu Komunikacji Elektronicznej Magdaleny Gaj z 30 czerwca 2015 r., DRP.WKP.710.2.2015.26,27.

Etel L., 2013 [w:], Ordynacja podatkowa. Komentarz, Kosikowski C., Etel L., LEX, Wydanie 5.

Grabowski M., 2020, Ustawa o ustugach platniczych. Komentarz, C.H. Beck, Wydanie 2.

Masłowski M., 2019, Acquiring a ustuga inicjowania transakcji płatniczej, „Europejski Przegląd Sądowy", nr 7.

Postanowienie SN z 27 listopada 1961 r., IV CR 634/61, LEX nr 104503

Postanowienie SN z 27 lutego 1962 r., III CZ 6/62, LEX nr 105787

Postanowienie SN z 27 stycznia 1969 r., I PZ 76/68, LEX nr 893

Postanowienie SN z 10 grudnia 2003 r., V CZ 127/03, LEX nr 136789

Postanowienie SN z 22 kwietnia 2004 r., II CZ 38/04, LEX nr 125539

Postanowienie SN z 27 października 2004 r., IV CZ 127/04, LEX nr 2703110

Postanowienie SN z 10 czerwca 2005 r., II CZ 49/05, LEX nr 154502

Postanowienie SN z 30 czerwca 2005 r., IV CZ 54/05, LEX nr 1231596

Postanowienie SN z 19 września 2007 r., III UZ 12/07, LEX nr 464911

Postanowienie SN z 19 czerwca 2008 r., V CZ 40/08, LEX nr 577243

Postanowienie SN z 26 września 2008 r., V CZ 54/08, LEX nr 512035

Postanowienie SN z 2 lutego 2011 r., II CZ 199/10, LEX nr 738551

Postanowienie SN z 19 września 2013 r., I PZ 6/13, LEX nr 1555074

Postanowienie SN z 21 listopada 2013 r., III CZ 50/13, LEX nr 1422034

Postanowienie SN z 21 stycznia 2015 r., IV CZ 96/14, LEX nr 1652704

Postanowienie SN z 20 lutego 2015 r., V CZ 120/14, LEX nr 1652415 
Postanowienie SN z 24 czerwca 2015 r., II CZ 29/15, LEX nr 1751288

Postanowienie SN z 25 stycznia 2017 r., IV CZ 96/16, LEX nr 2242293

Postanowienie SN z 13 kwietnia 2018 r., I CZ 39/18, LEX nr 2490924

Postanowienie SN z 18 grudnia 2018 r., IV CZ 68/18, LEX nr 2617936

Radziszewski E., 2013, Bank jako instytucja zaufania publicznego. Gwarancje prawne $i$ instytucjonalne, Poradnik klienta ustug finansowych, KNF, Warszawa.

Rozporządzenie Ministra Sprawiedliwości z dnia 21 marca 2016 r. w sprawie sposobu uiszczania opłat sądowych w sprawach cywilnych, Dz.U. 2016, poz. 408.

Rozporządzenie Rady Ministrów z dnia 16 grudnia 2003 r. w sprawie wysokości oraz szczegółowych zasad pobierania wpisu w postępowaniu przed sądami administracyjnymi, Dz.U. 2003, nr 221, poz. 2193.

Uchwała NSA 7 sędziów NSA z 22 stycznia 2018 r., I FPS 3/17, LEX nr 2428199

Uchwała SN z 16 grudnia 1983 r., III PZP 47/83, LEX nr 2960

Uchwała SN z 4 stycznia 1995 r., III CZP 164/94, LEX nr 4159

Uchwała SN z 25 czerwca 2003 r., III CZP 28/03, LEX nr 78600

Uchwała SN z 21 stycznia 2011 r., III CZP 115/10, LEX nr 685312

Uchwała SN z 26 lutego 2014 r., III CZP 112/13, LEX nr 1433736

Ustawa z dnia 17 listopada 1964 r. - Kodeks postępowania cywilnego, Dz.U. 1964, nr 43, poz. $296 \mathrm{ze} \mathrm{zm}$.

Ustawa z dnia 19 sierpnia 2011 r. o usługach płatniczych, Dz.U. 2011, nr 199, poz. 1175 ze zm.

Ustawa z dnia 23 listopada 2012 r. Prawo pocztowe, Dz.U. 2012, poz. 1529 ze zm.

Ustawa z dnia 28 lipca 2005 r. o kosztach sądowych w sprawach cywilnych, Dz.U. 2005, nr 167, poz. 1398 ze zm.

Ustawa z dnia 29 sierpnia 1997 r. - Ordynacja podatkowa, Dz.U. 1997, nr 137, poz. 926 ze zm.

Ustawa z dnia 29 sierpnia 1997 r. - Prawo bankowe., Dz.U. 1997, nr 140, poz. 939 ze zm.

Ustawa z dnia 30 sierpnia 2002 r. Prawo o postępowaniu przed sądami administracyjnymi, Dz.U. 2002, nr 153, poz. 1270.

Ustawa z dnia 5 września 2008 r. o komercjalizacji państwowego przedsiębiorstwa użyteczności publicznej „Poczta Polska”, Dz.U. 2008, nr 180, poz. 1109 ze zm.

Wyrok SN z 12 lipca 1996 r., III CRN 75/96, „Palestra” 1996, nr 11-12.

Wyrok SO w Siedlcach z 5 lipca 2019 r., IV U 195/19, LEX nr 2705114

\title{
PAYMENT OF COURT FEES VIA PAYMENT SERVICE PROVIDERS
}

\begin{abstract}
The purpose of the article is to show that the date of initiating a payment order is decisive for meeting the deadline of payments of court fees in civil and administrative court proceedings, rather than the date of receipt of funds by the court (the date of crediting the court's account), regardless of the operator through which the transaction has been initiated provided that it a payment service provider. Subject of the analysis is in particular the overview of the current jurisprudence of the Supreme Court and the Supreme Administrative Court.
\end{abstract}

Keywords: court fee, civil proceedings, administrative court proceedings, payment service provider, payment service. 